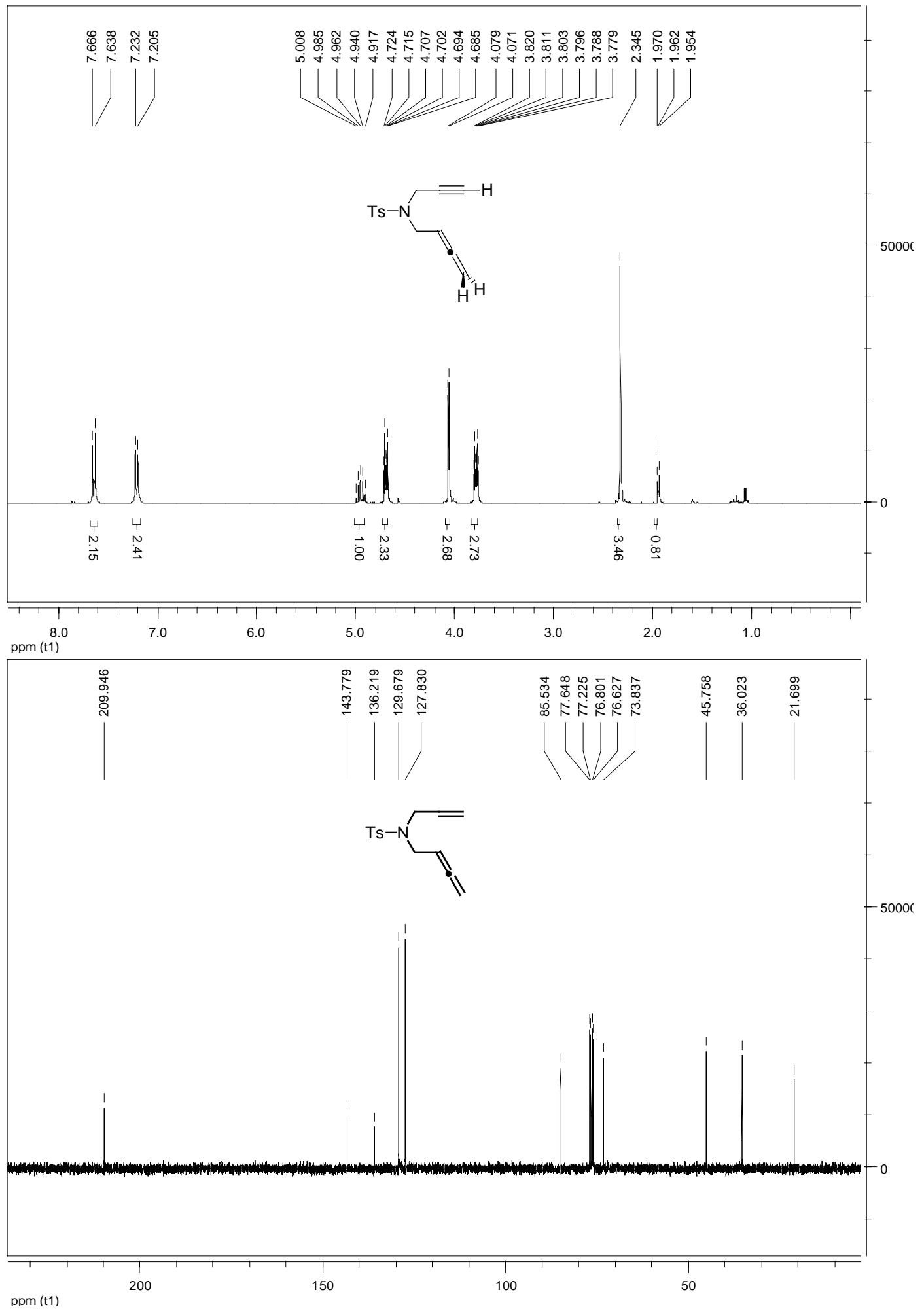



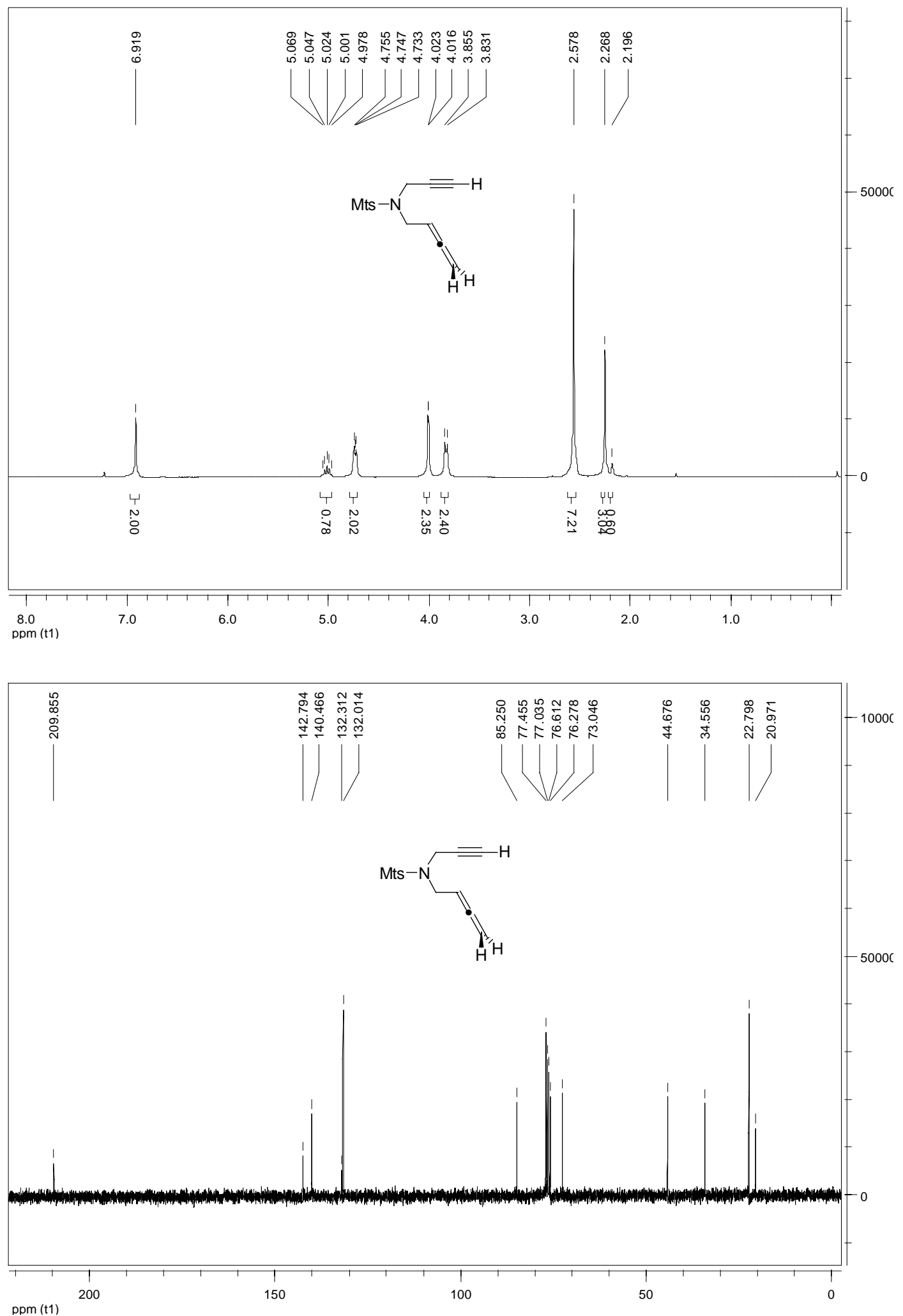


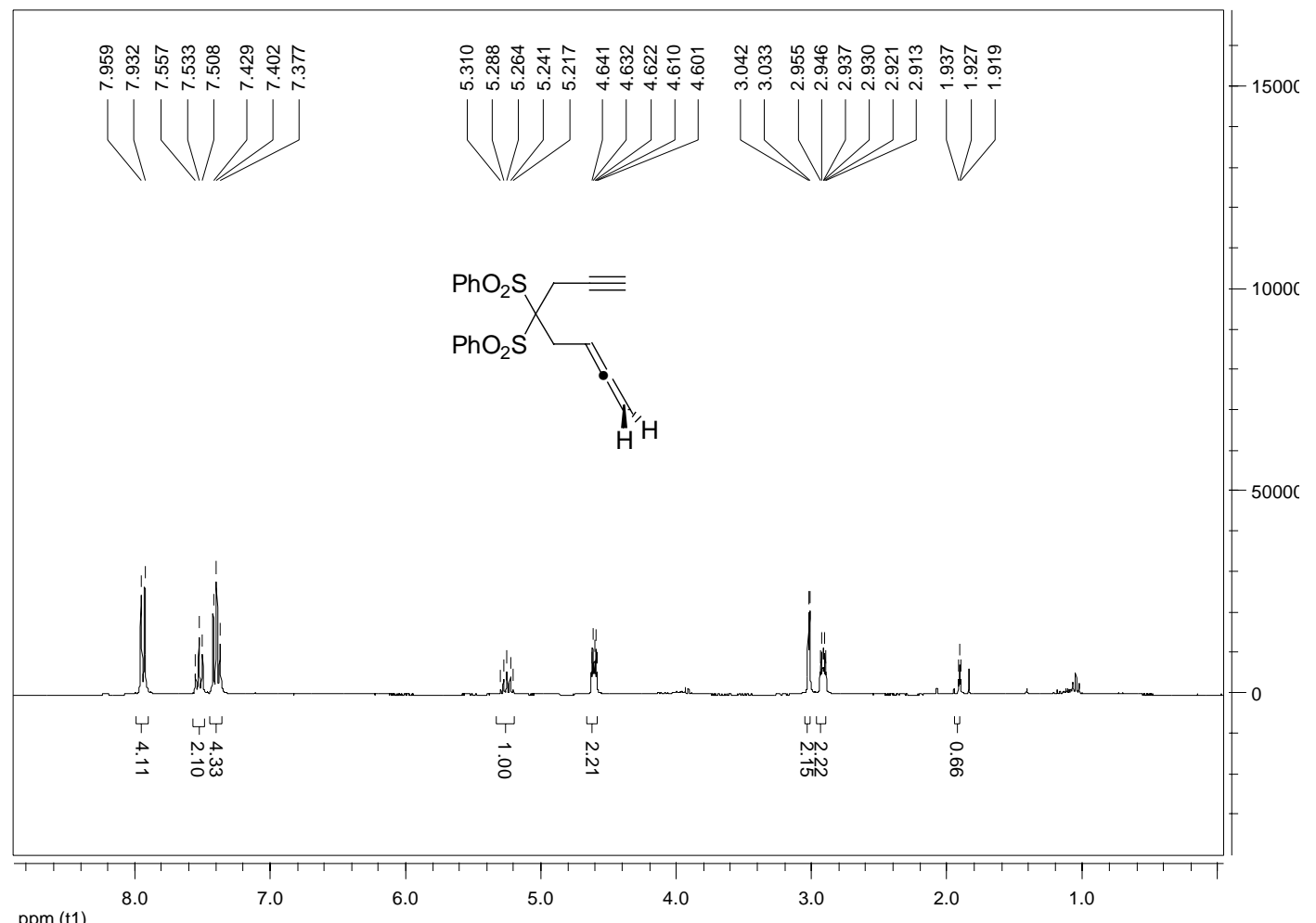

ppm (t1)

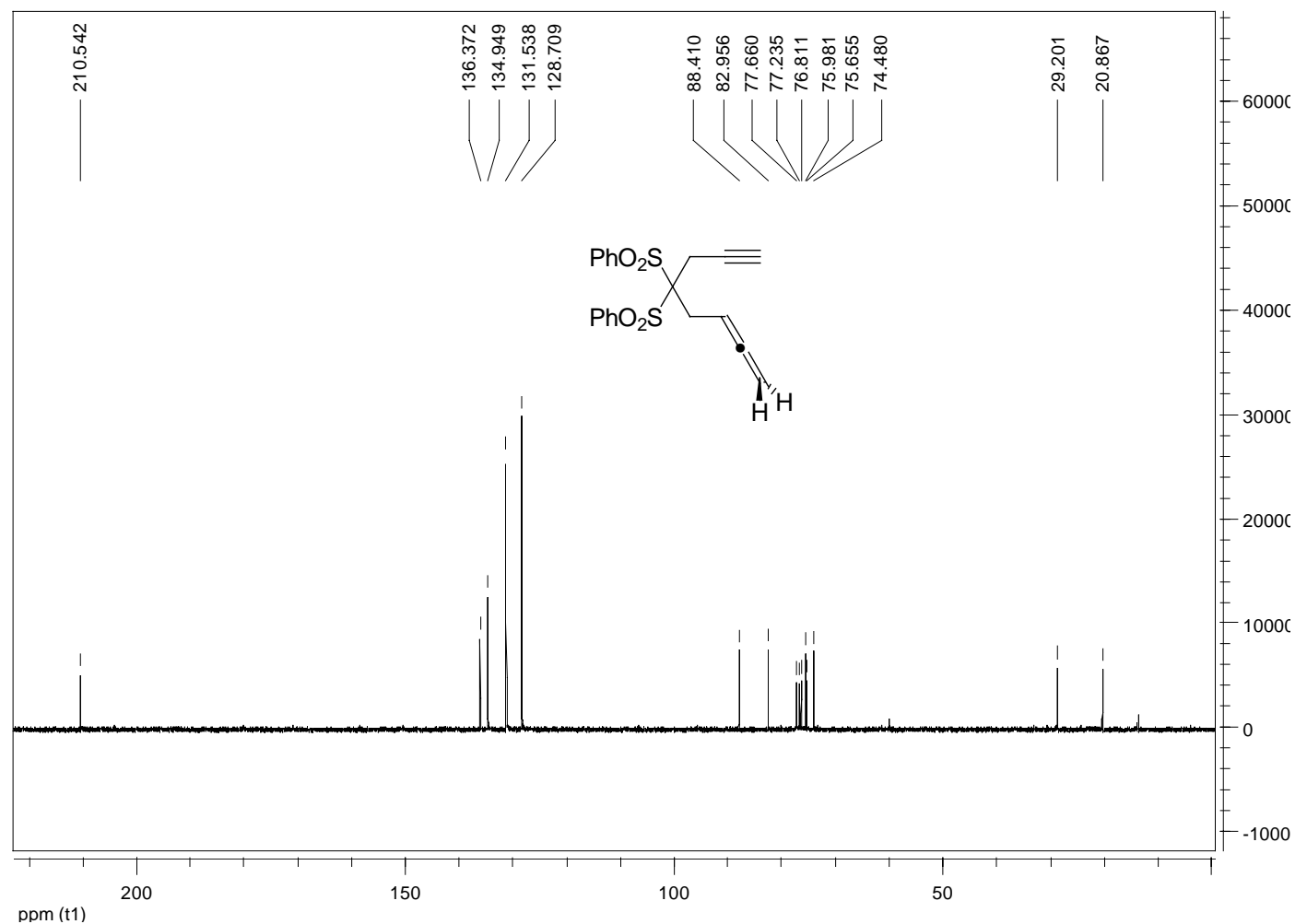



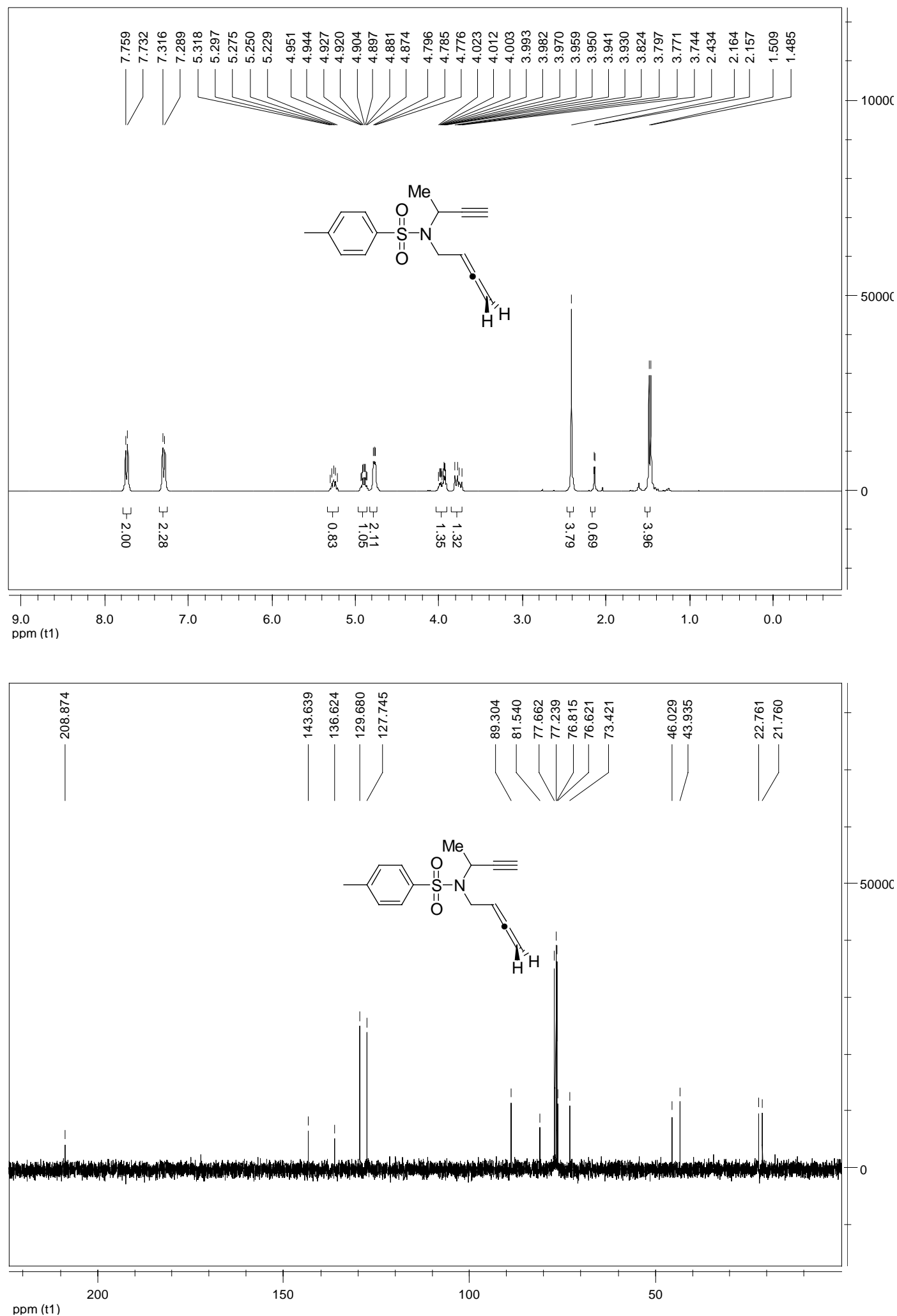

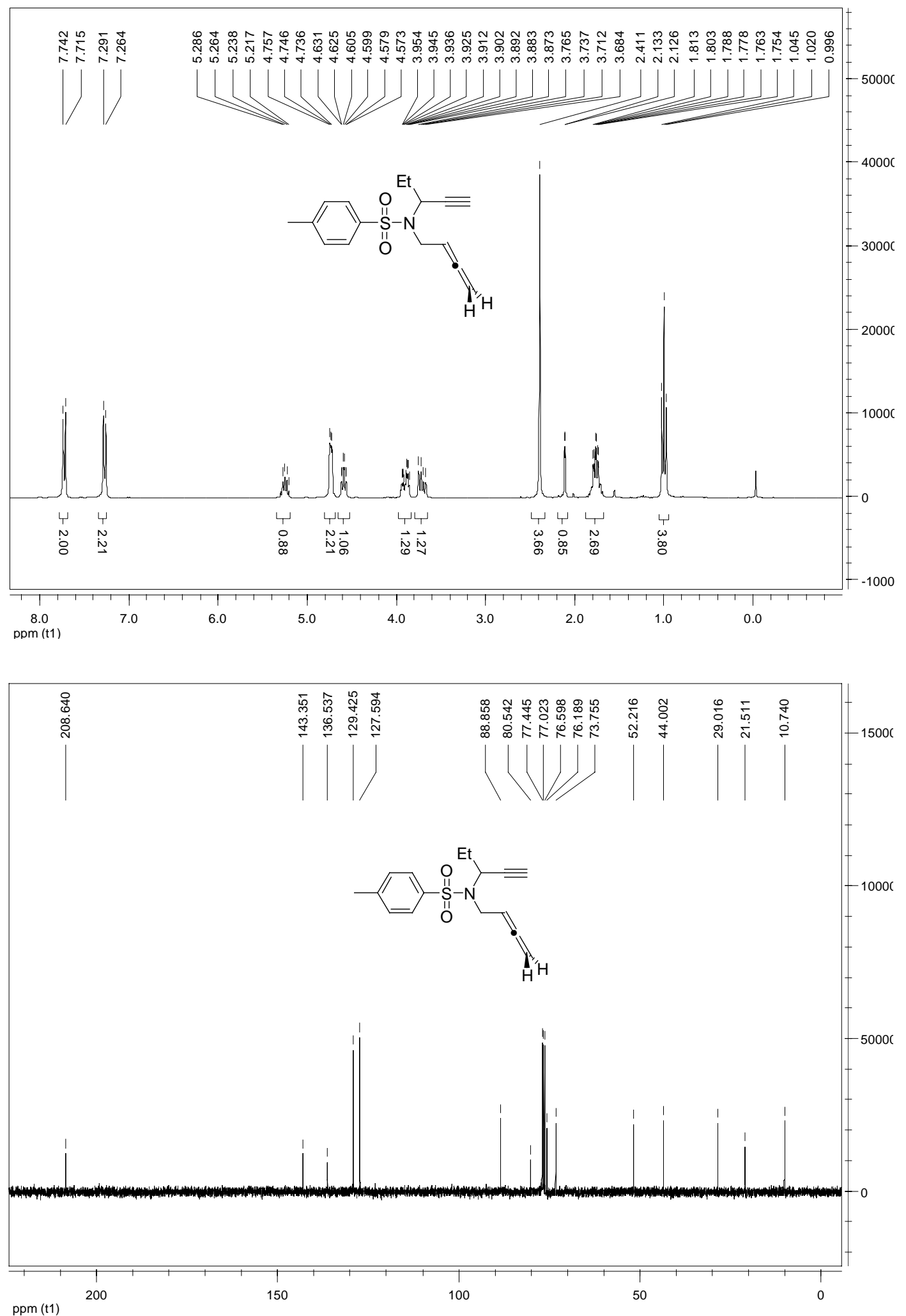

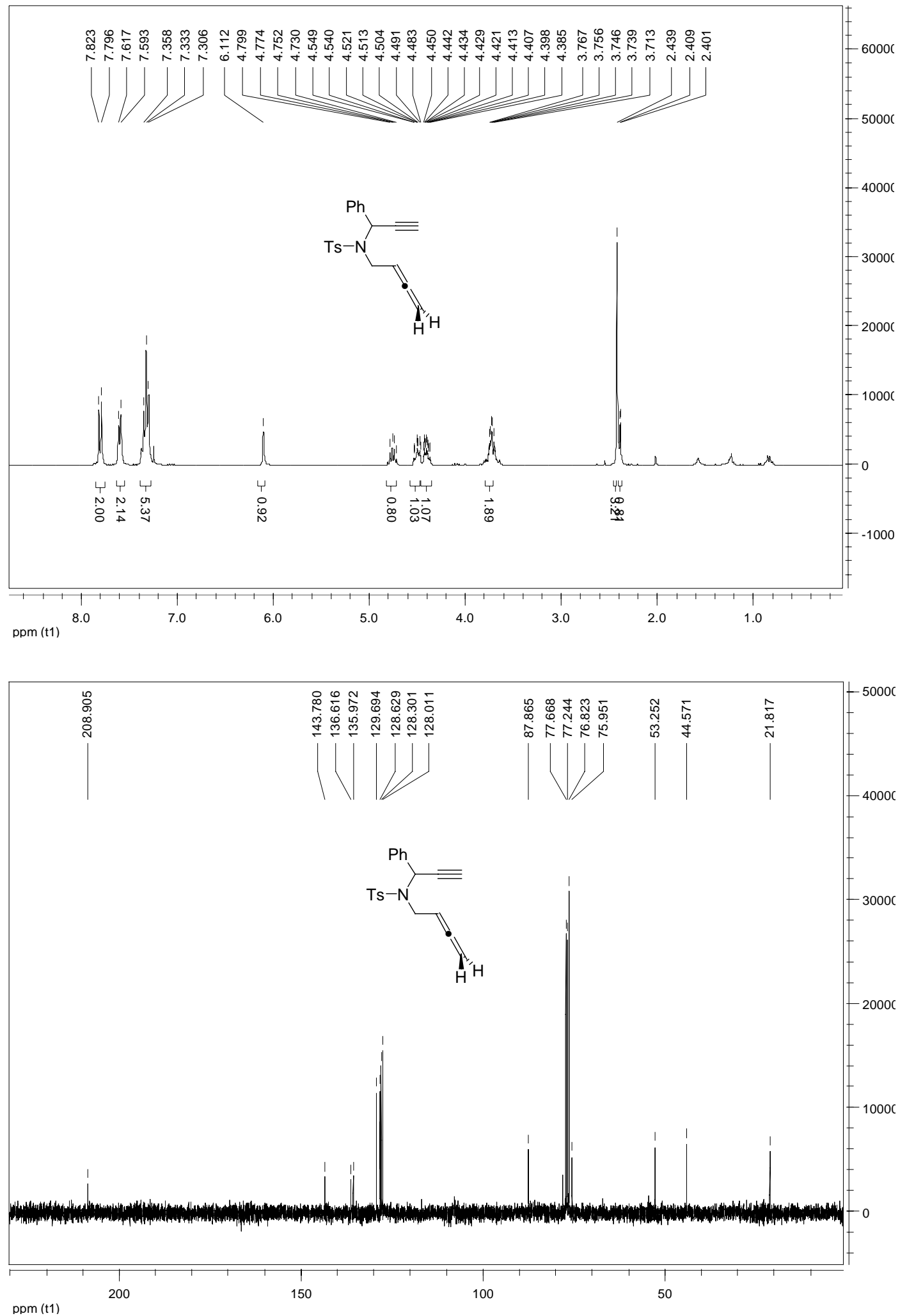

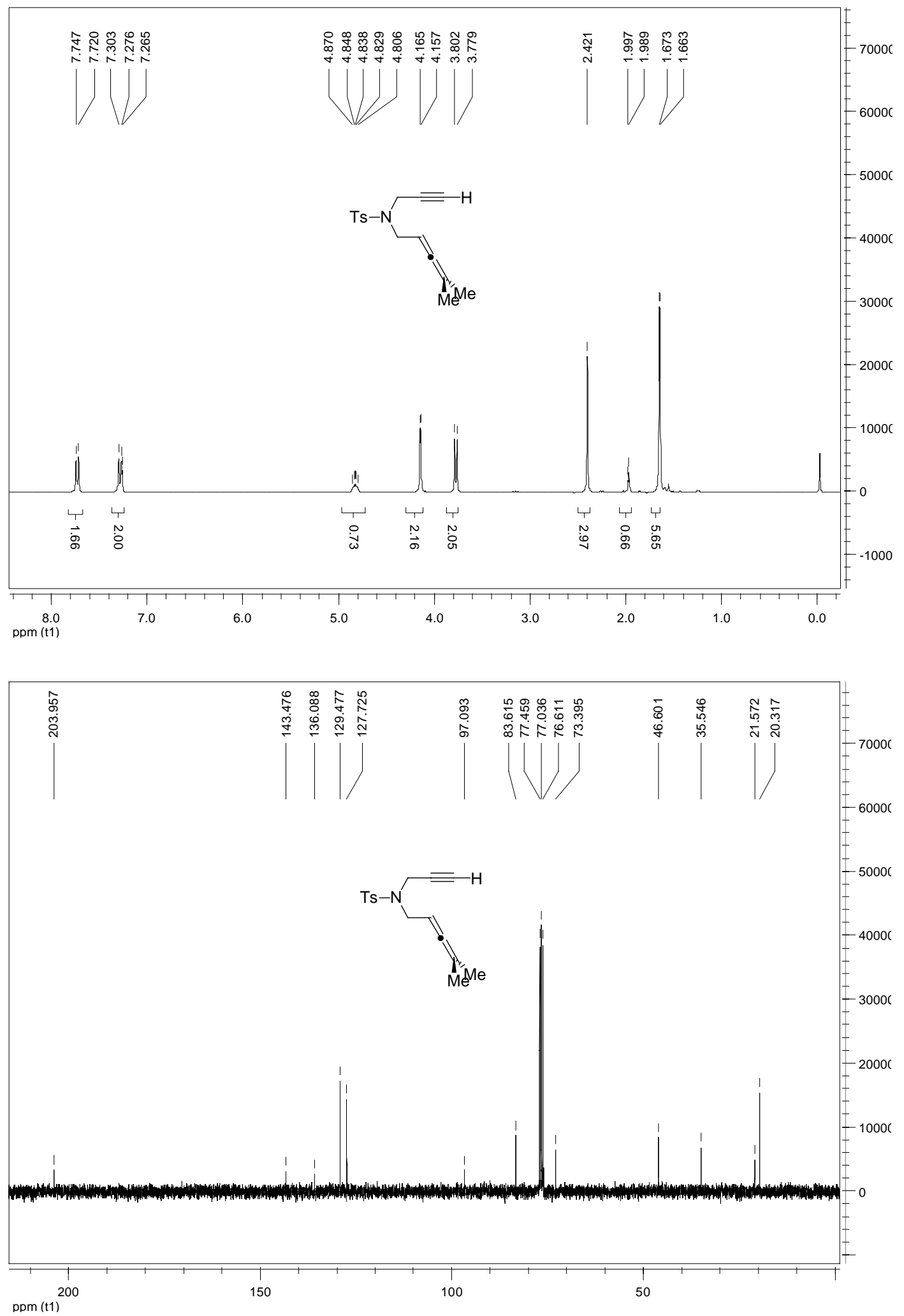

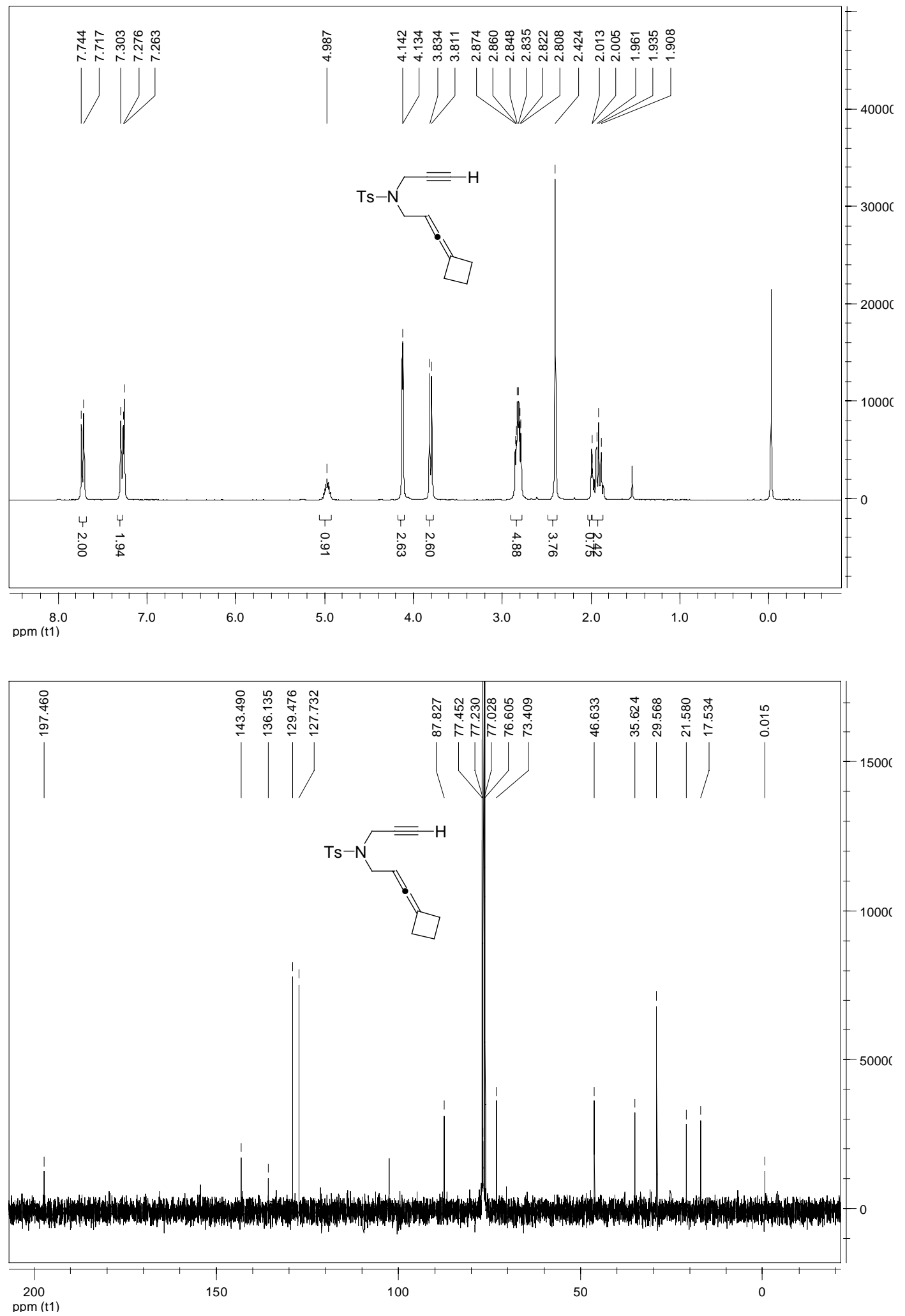

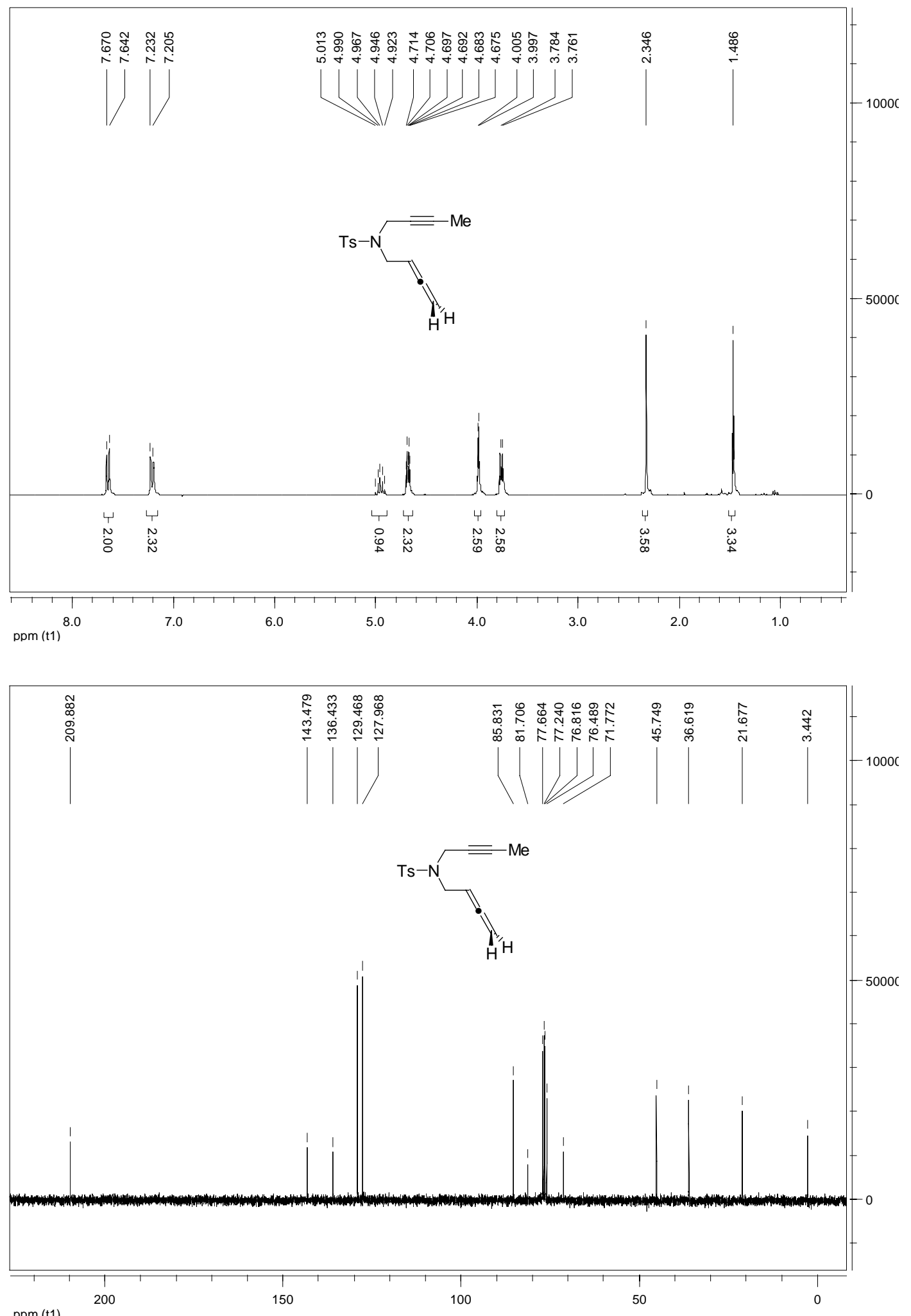

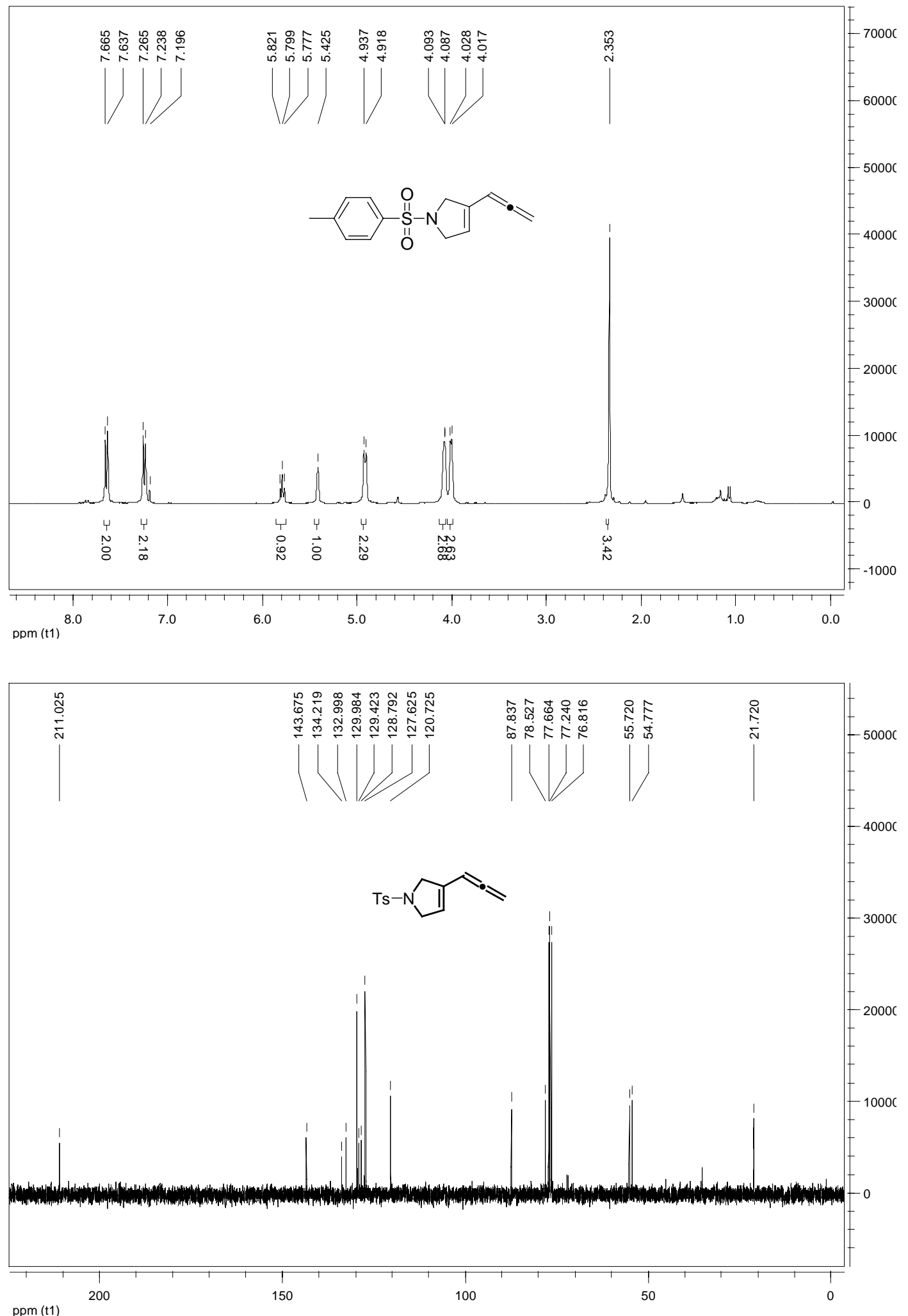

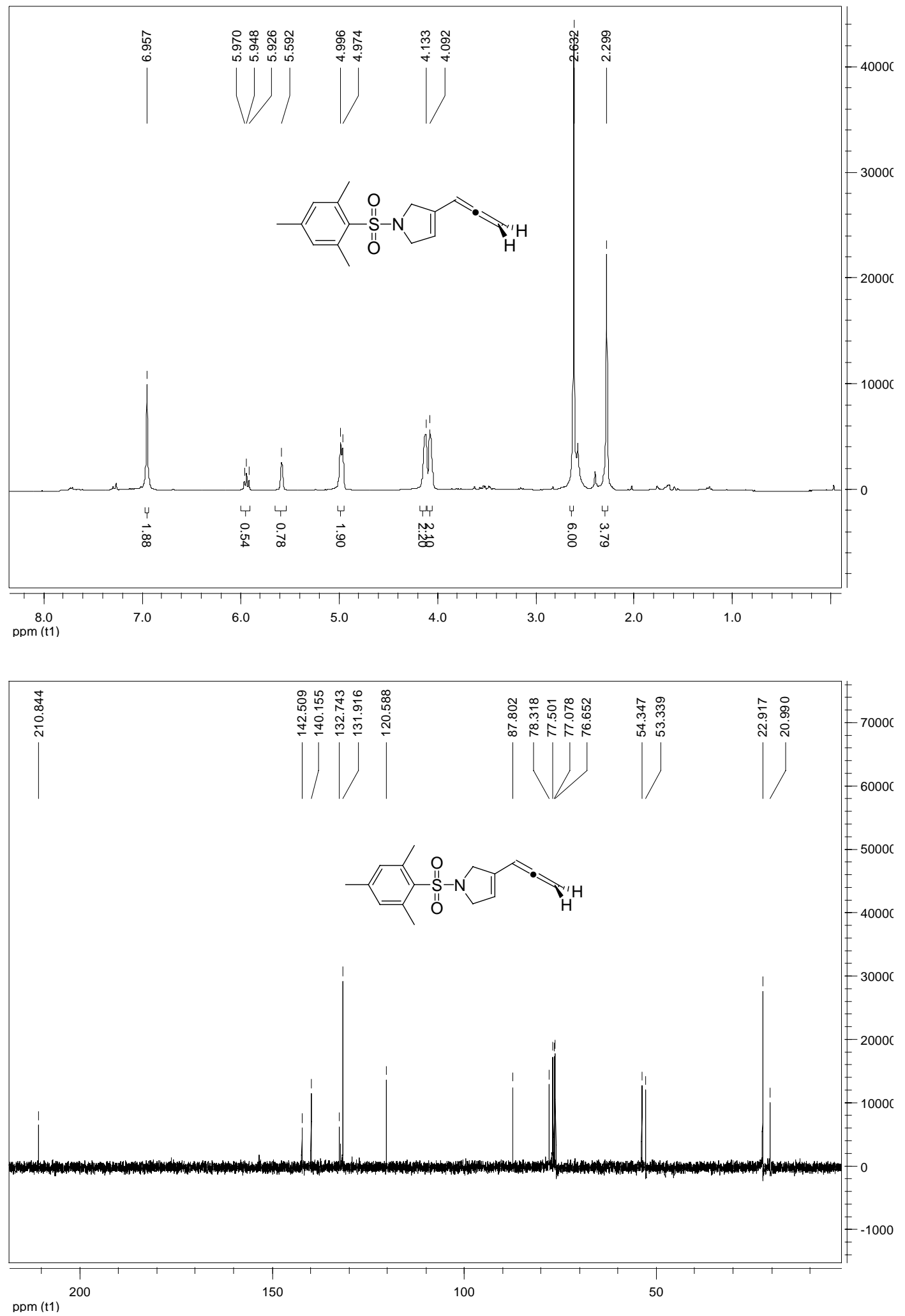

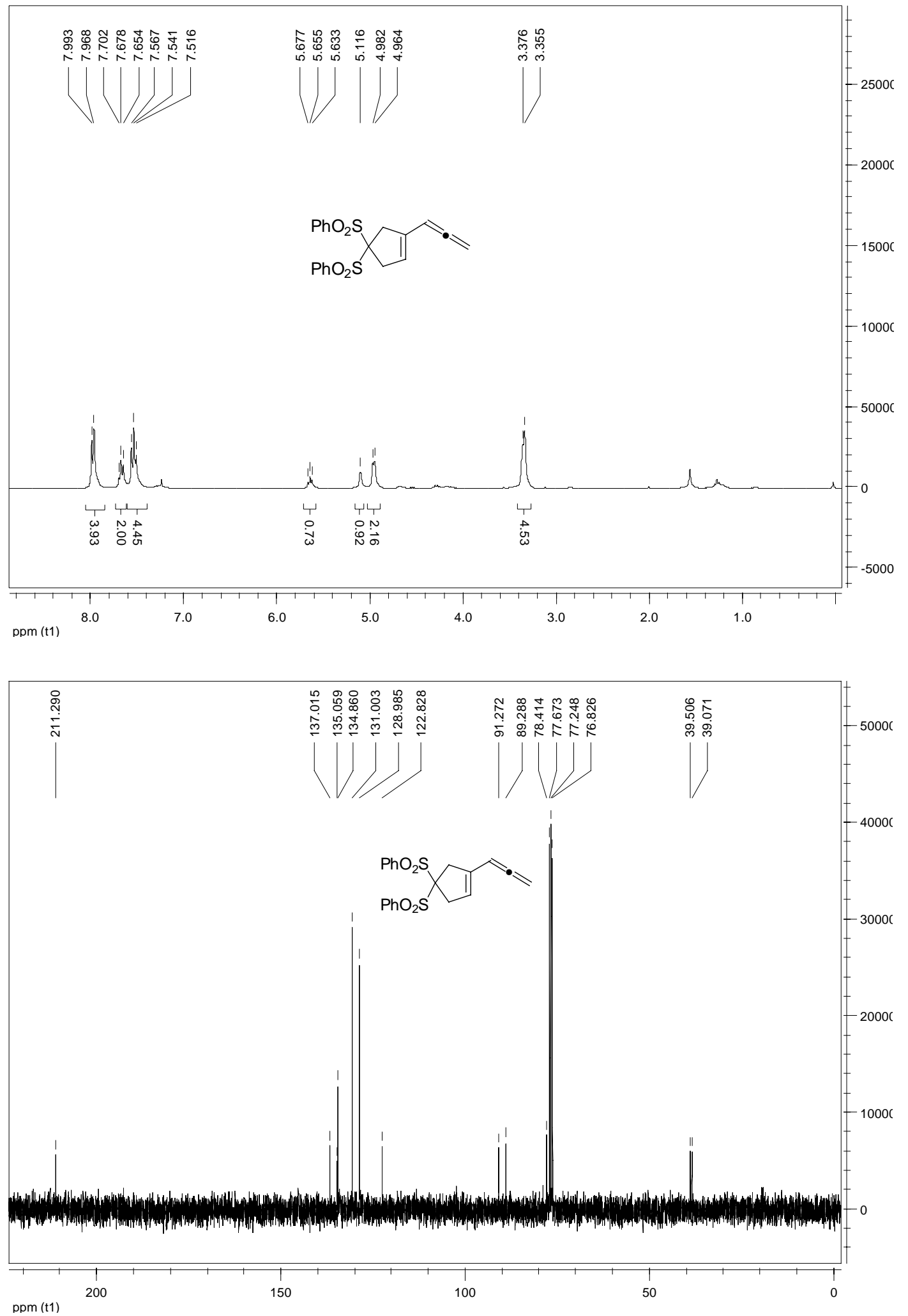


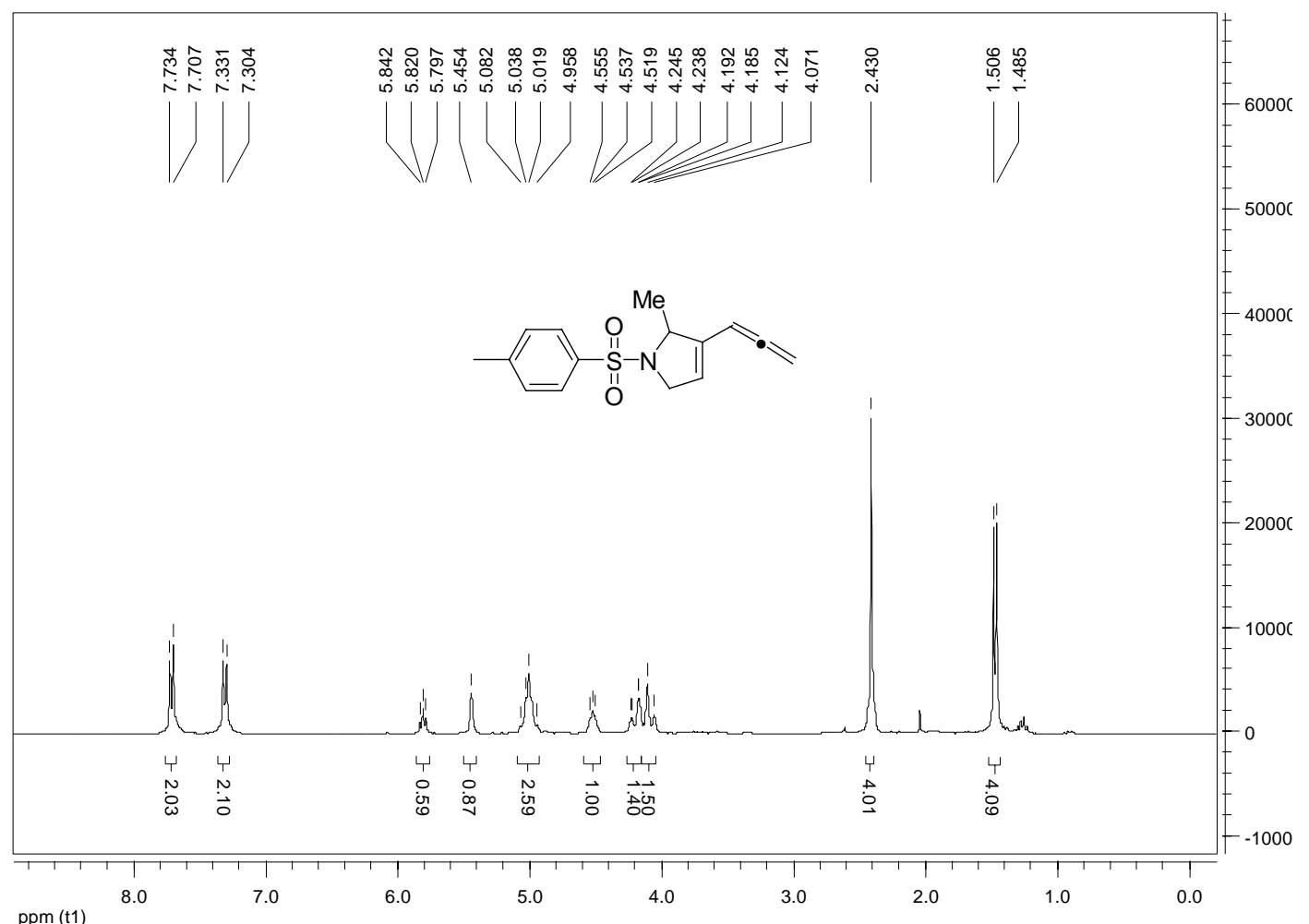

ppm (t1)

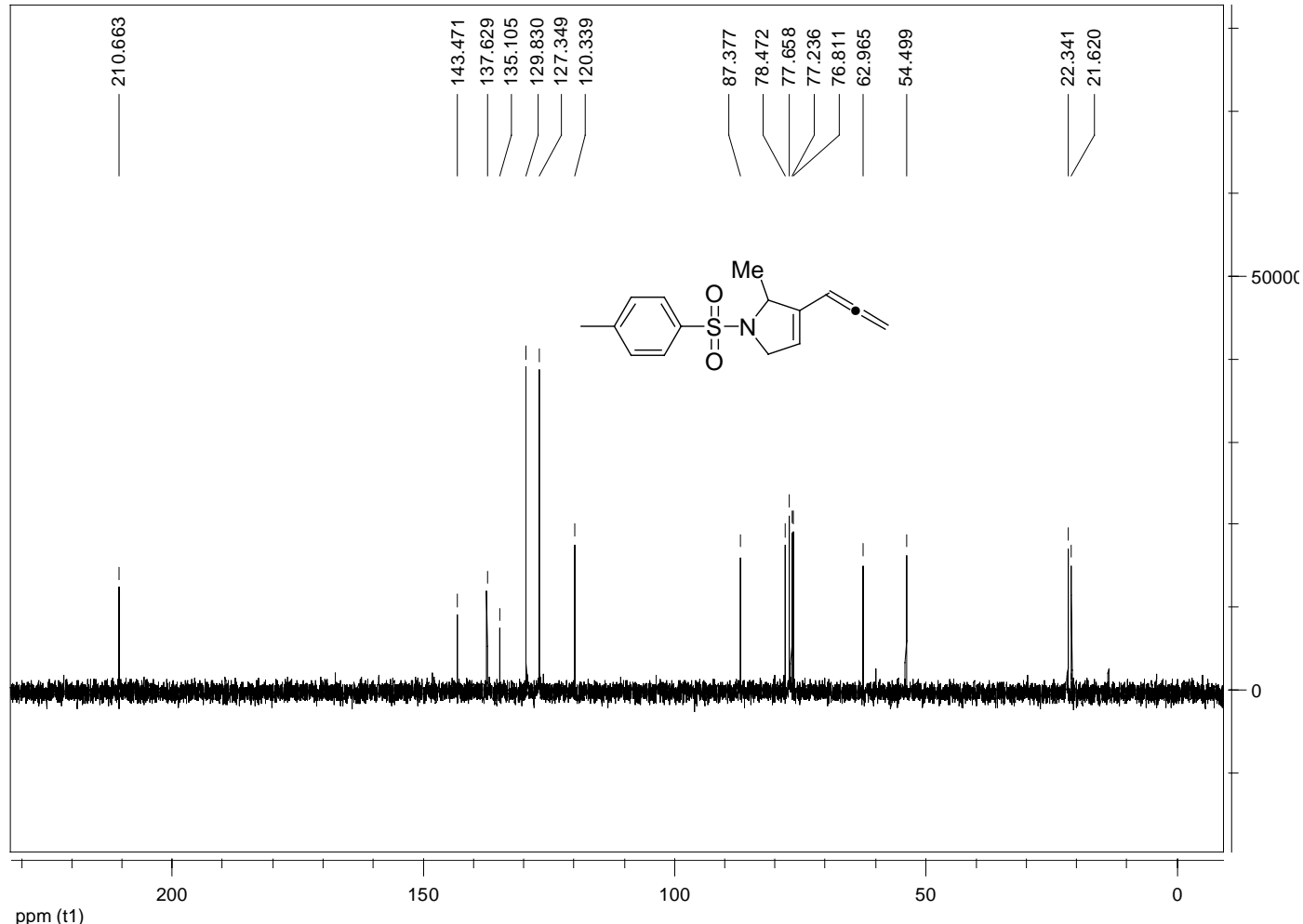



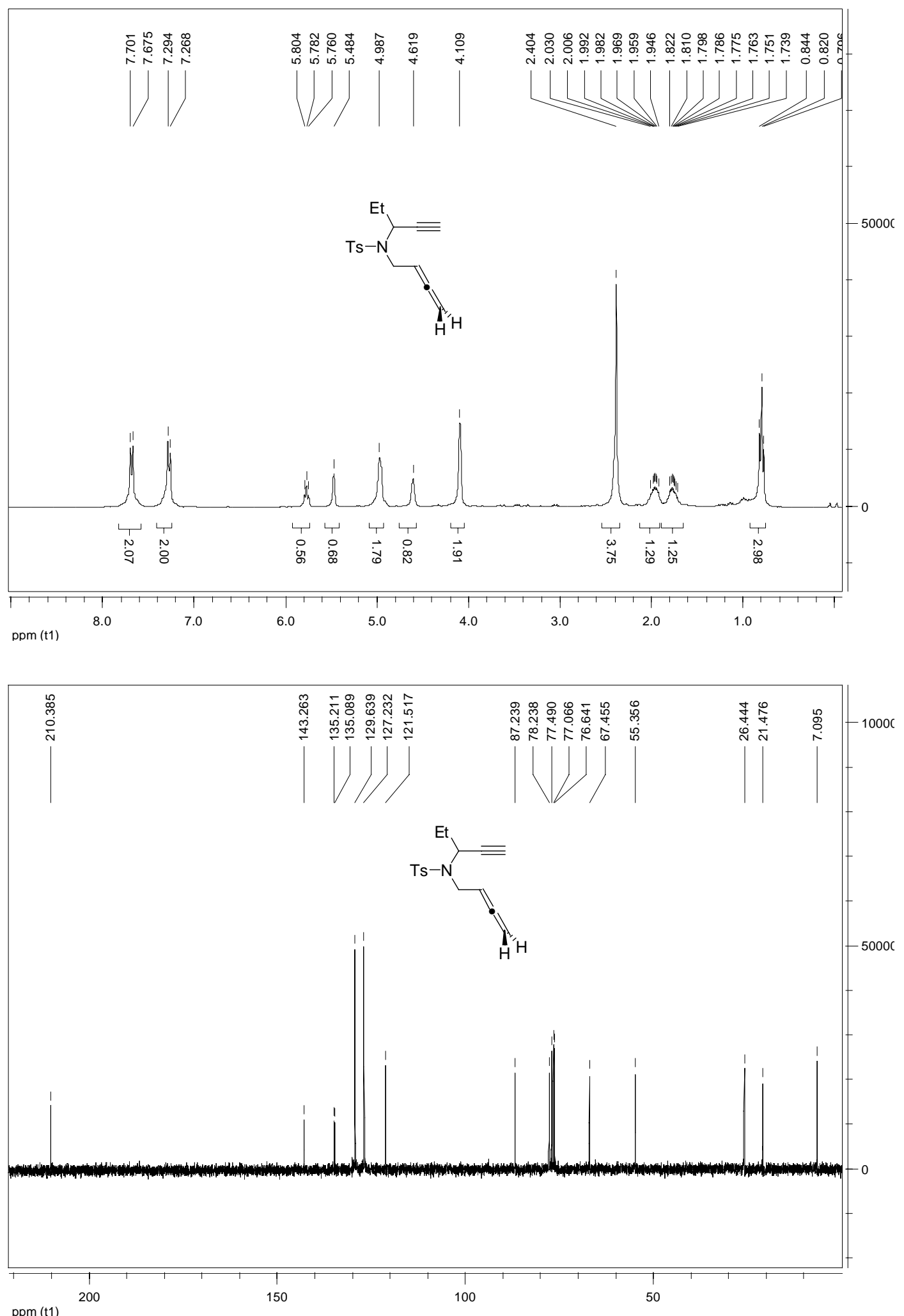


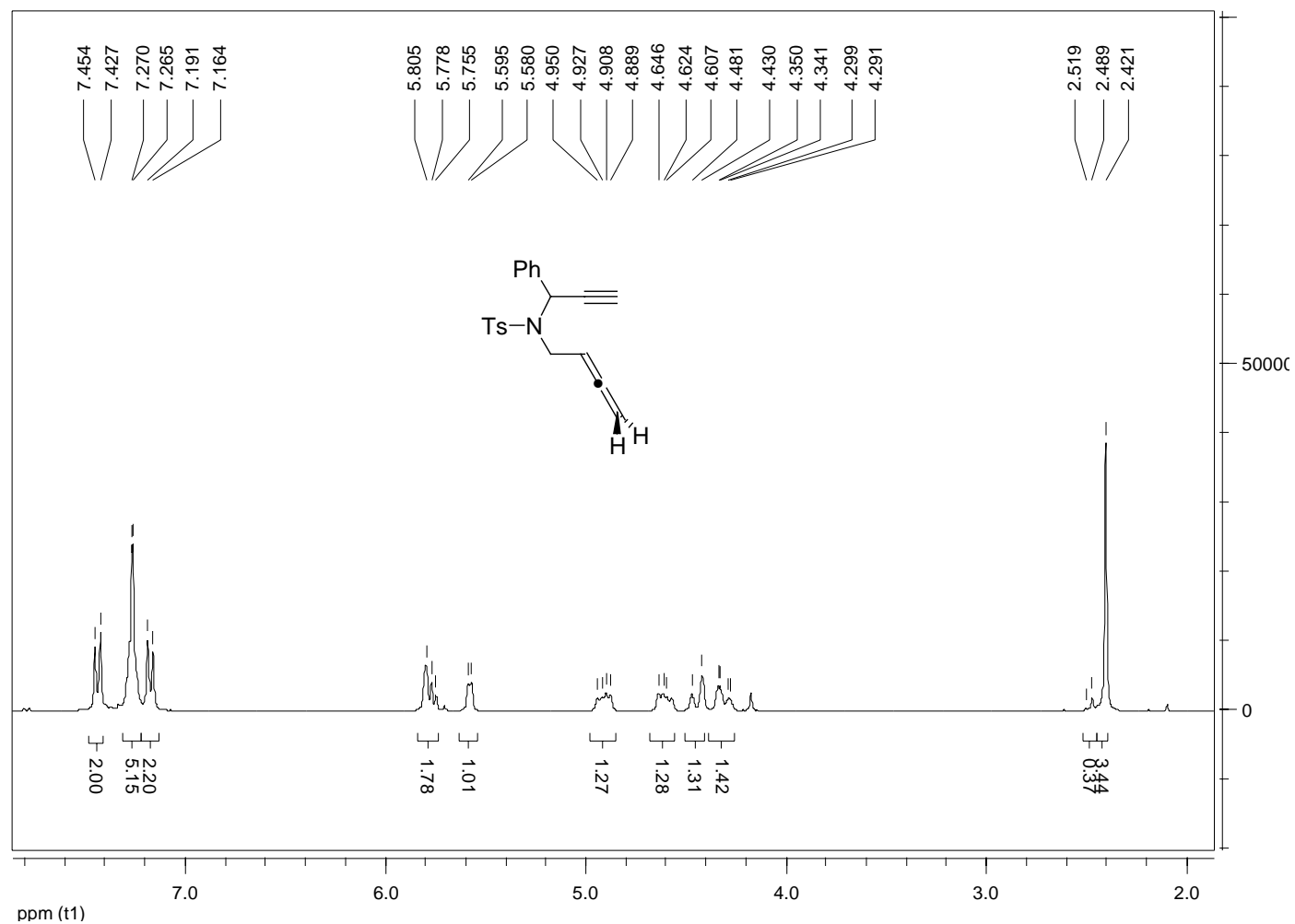

ppm (t1)

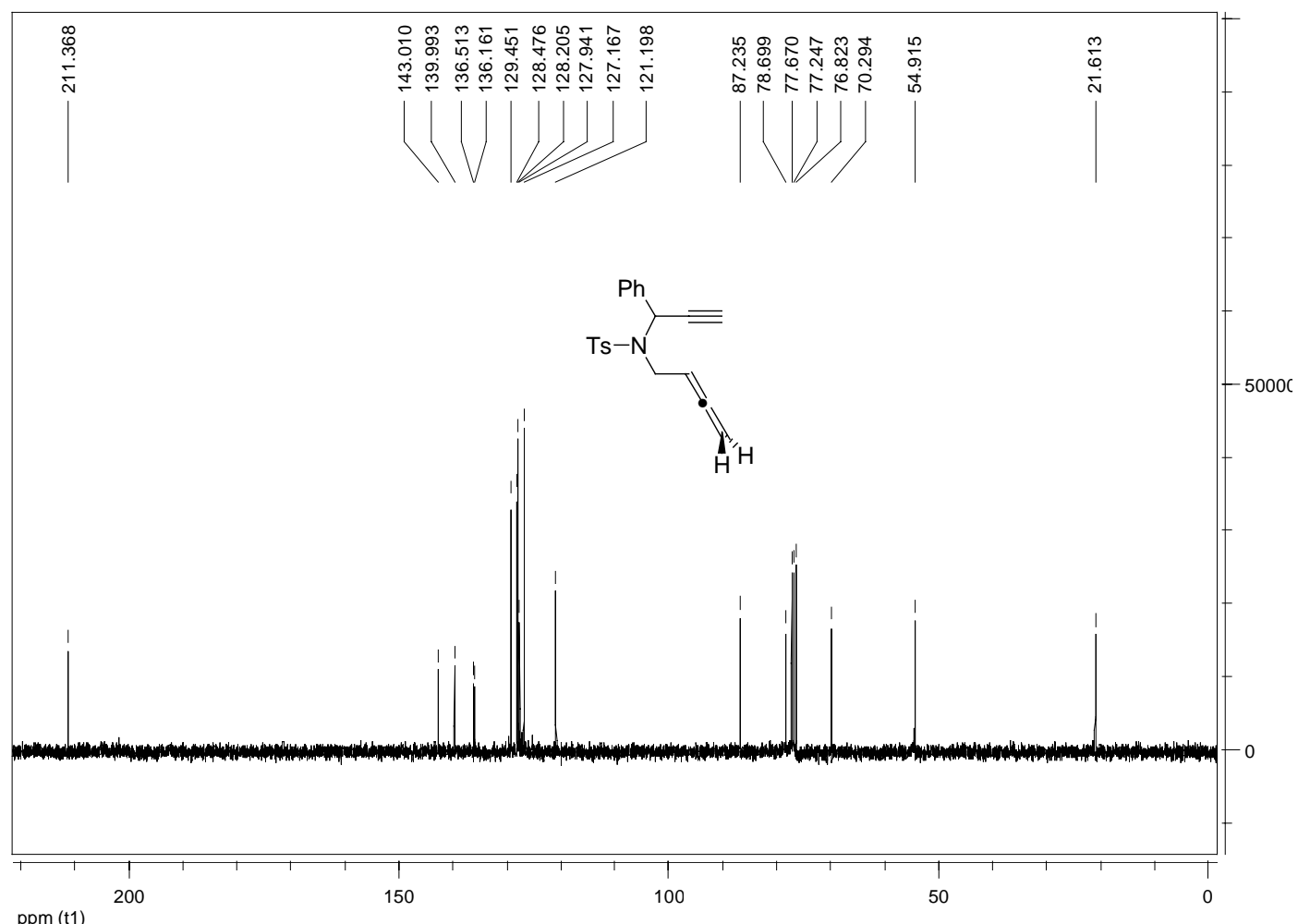



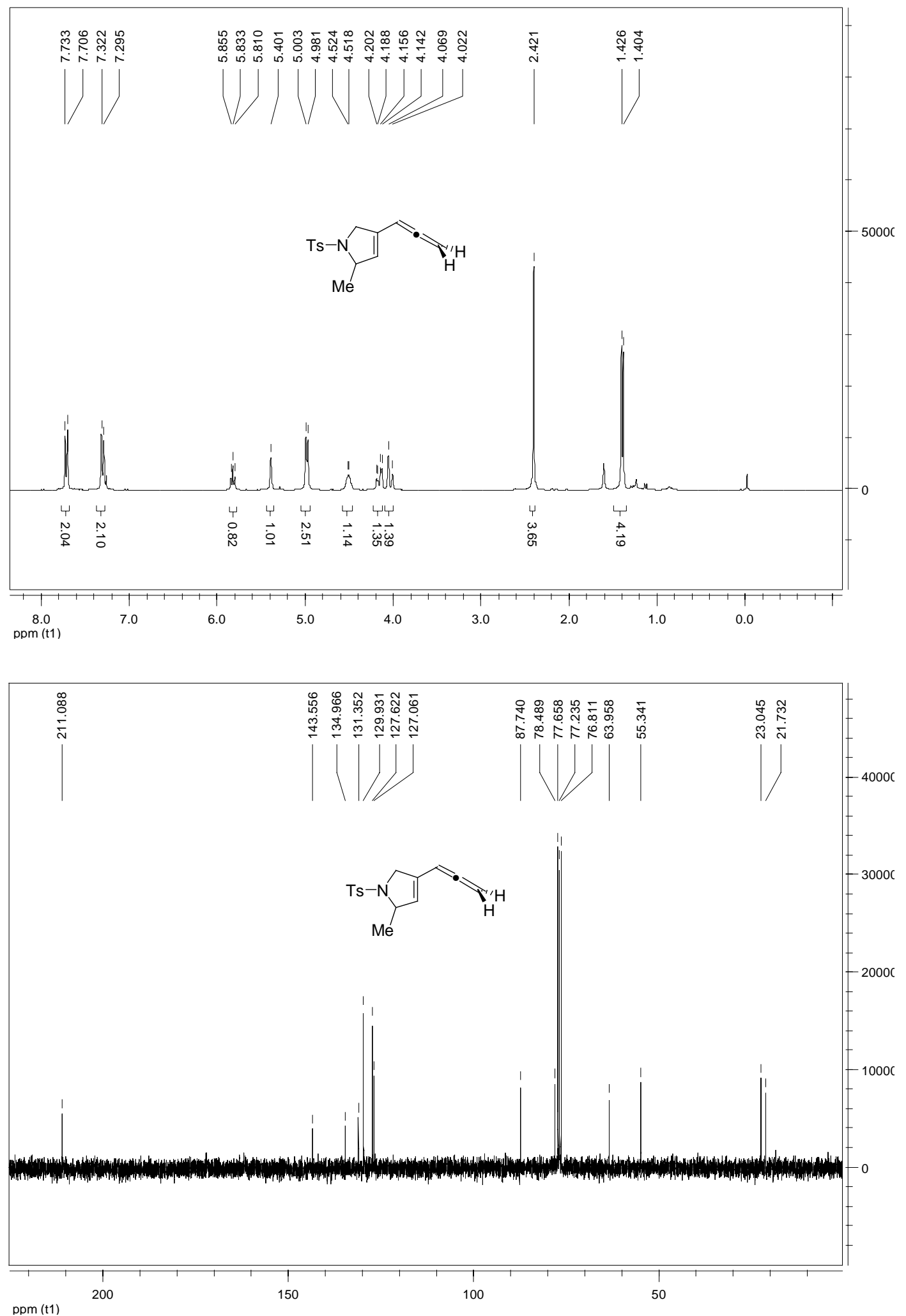

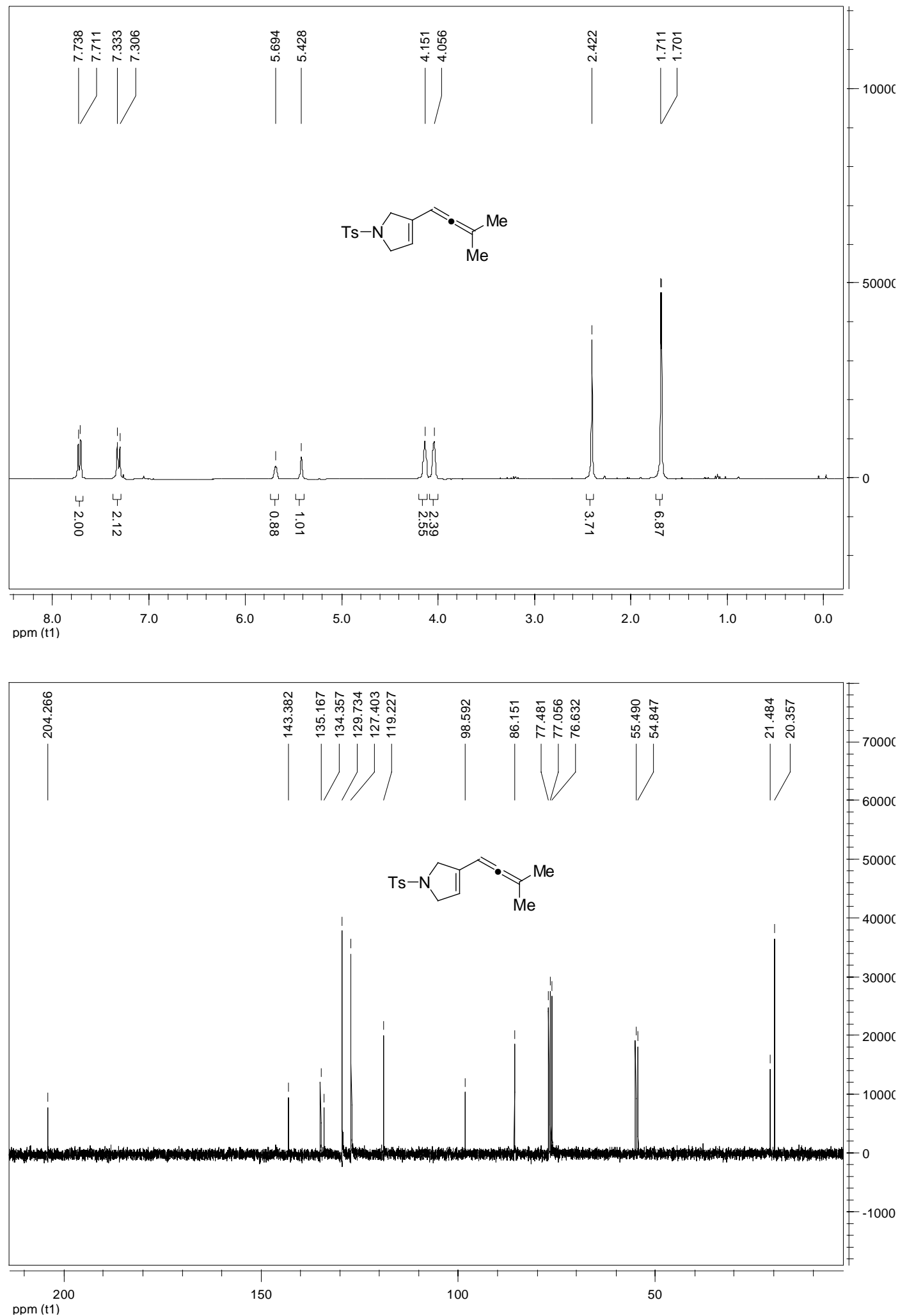

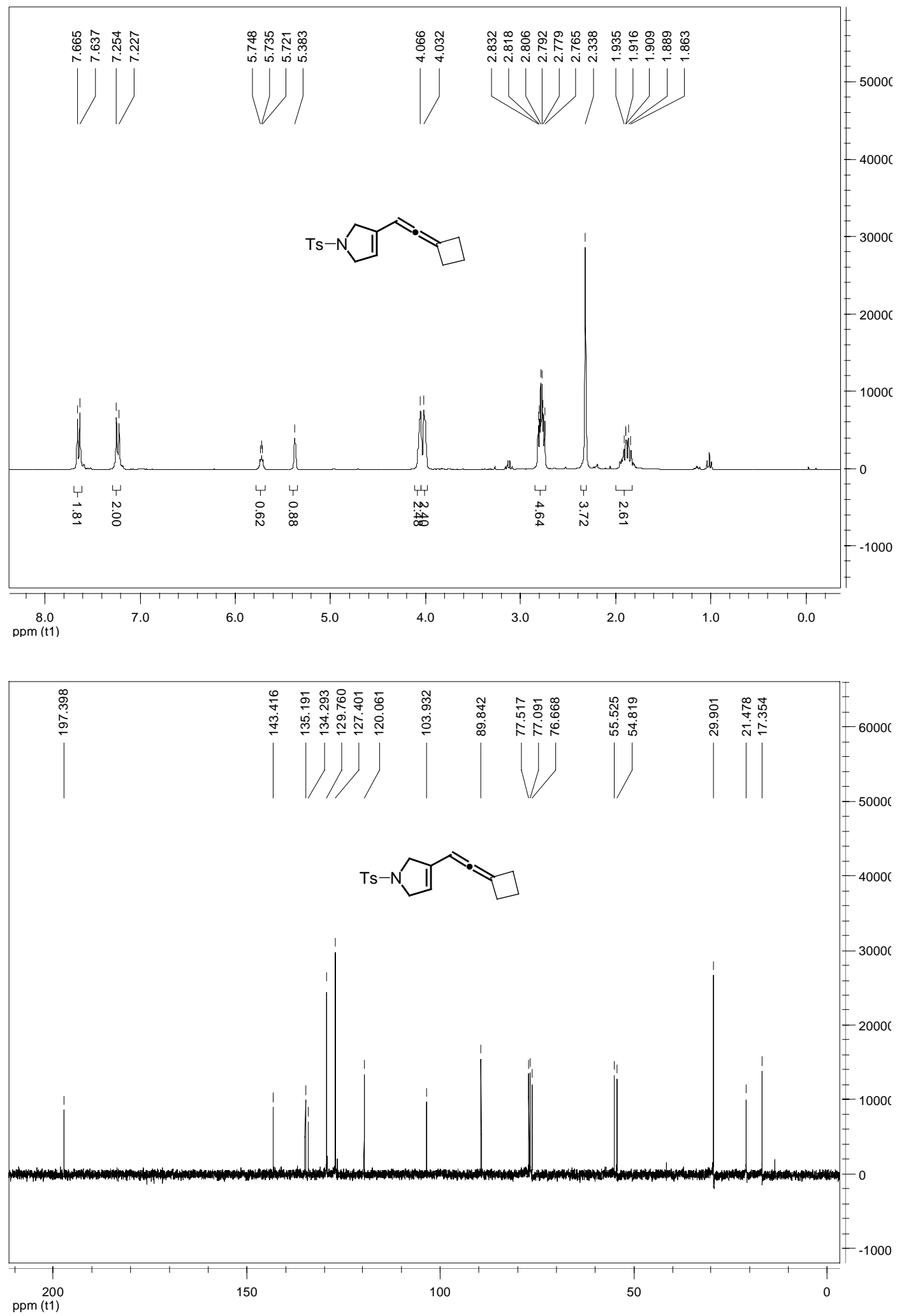

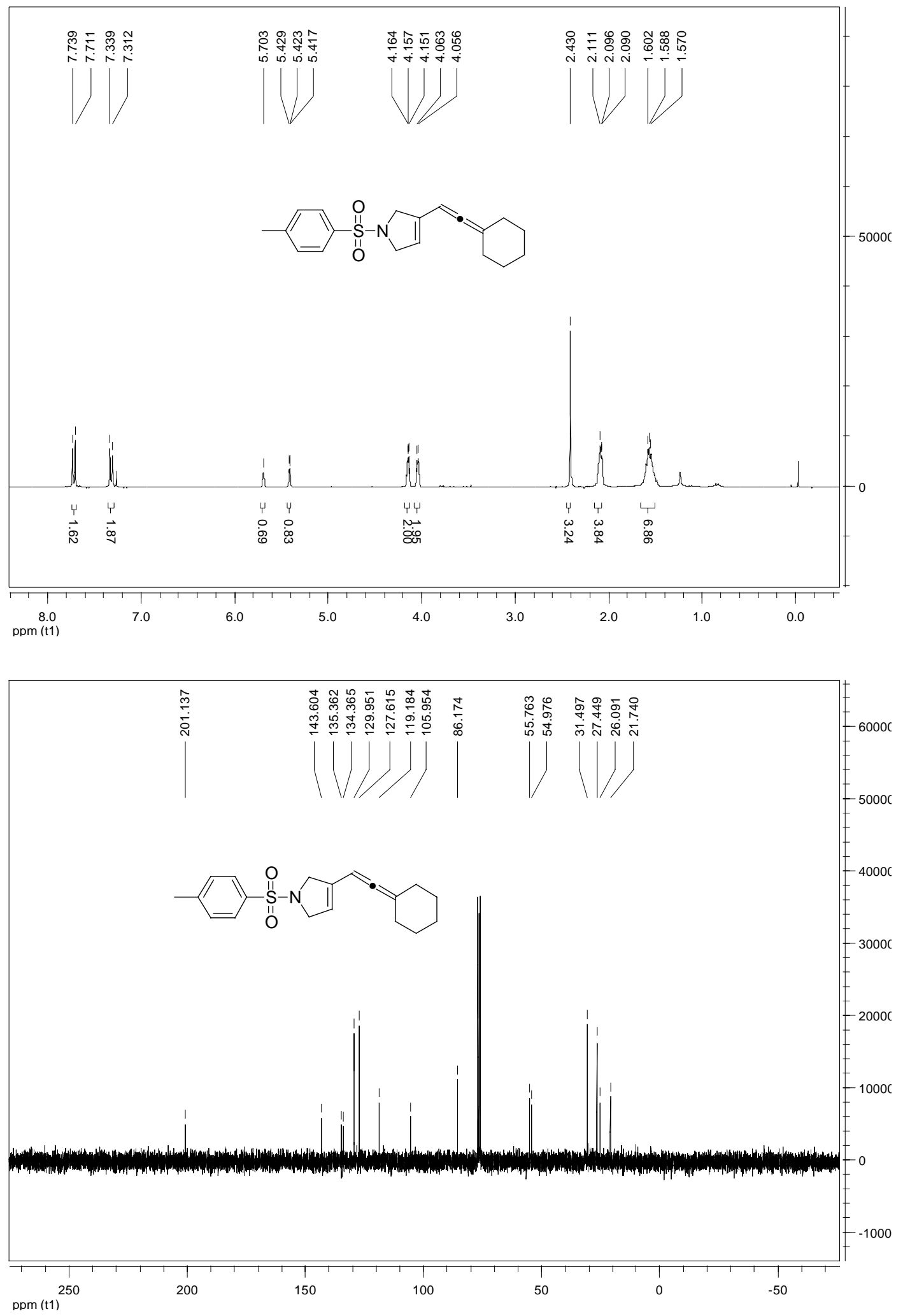


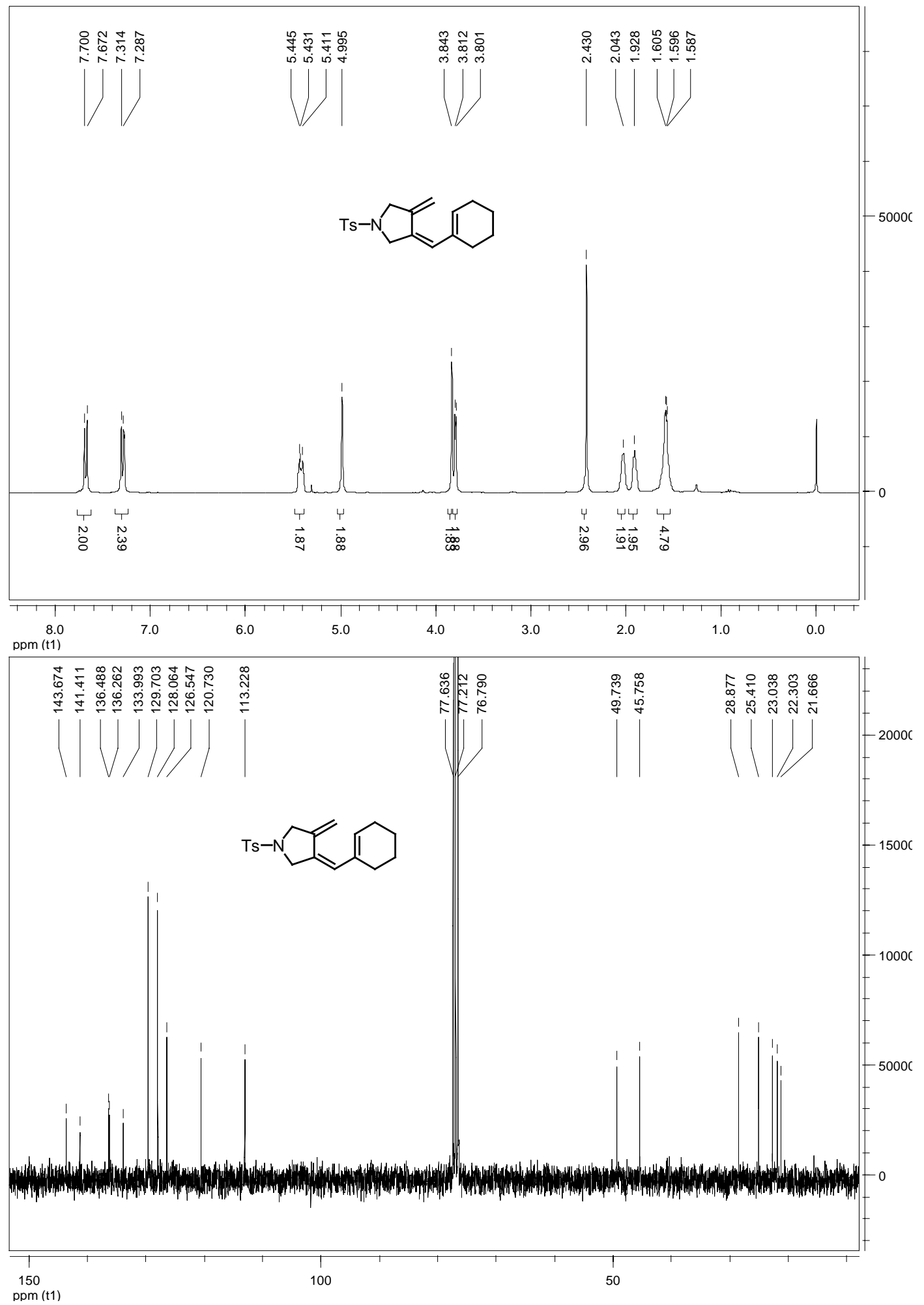



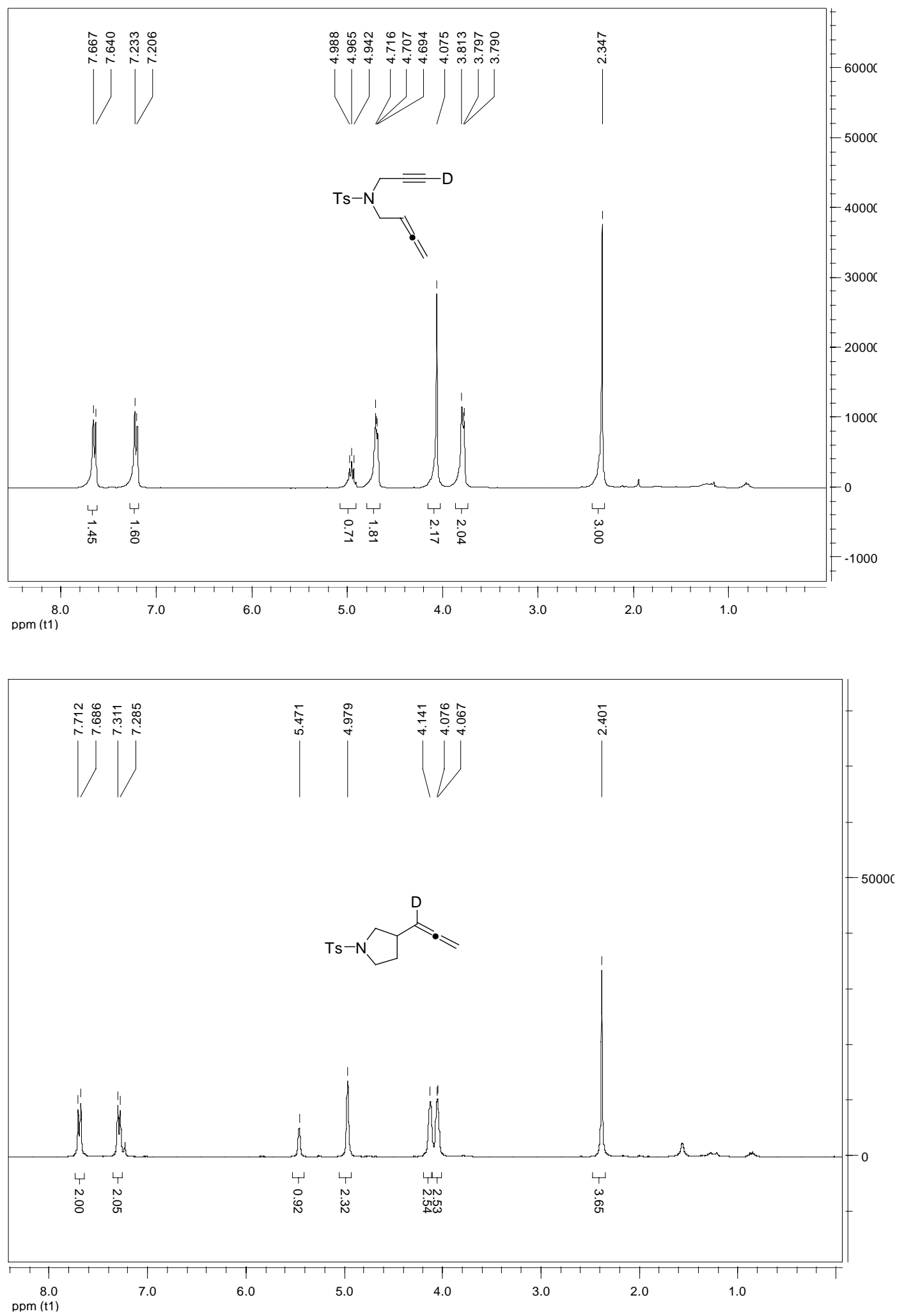
1a-(d) D-NMR
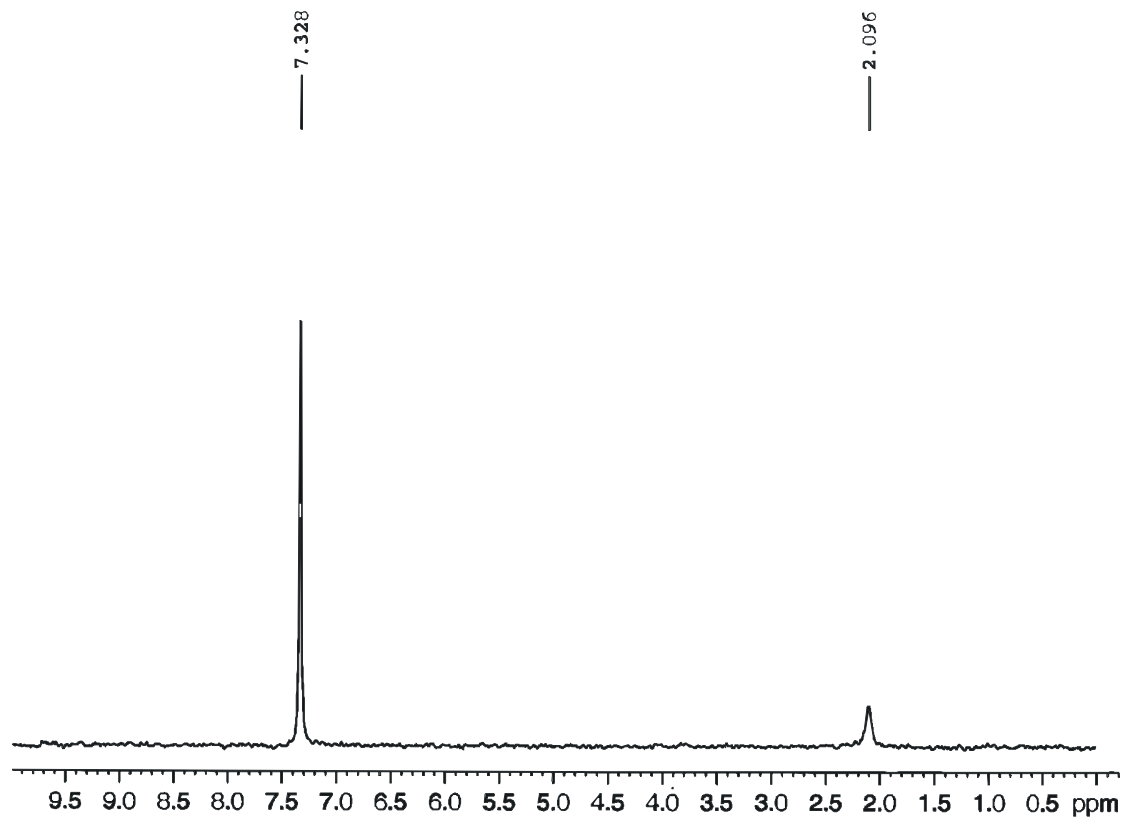

\section{2a-(d) D-NMR}
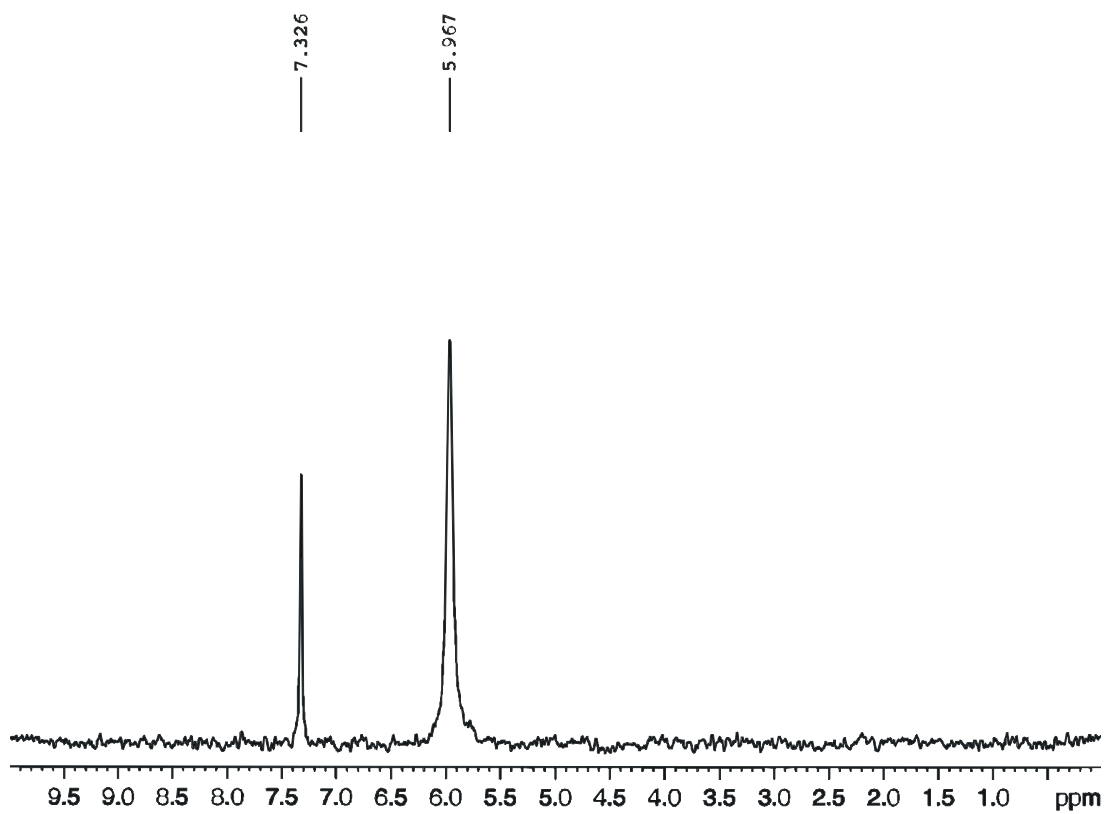